\title{
ENVIRONMENTAL CARRYING CAPACITY ANALYSIS BASED ON WATER RESOURCES (CASE STUDY OF EAST SURABAYA AREA)
}

\author{
Enggar HASTOYUANDO ${ }^{1}$, Widodo BRONTOWIYONO ${ }^{1}$, Nur Aini Iswati HASANAH ${ }^{1,{ }^{*}}$ \\ ${ }^{1}$ Department of Environmental Engineering, Universitas Islam Indonesia, Yogyakarta 55584, \\ Indonesia. \\ corresponding author: hasanah@uii.ac.id.
}

\begin{abstract}
East Surabaya, an area that is developing intensively, is known for its excessive problems, including a water shortage which reoccurs every year. The main objective of this study is to investigate the environmental carrying capacity based on the available water resources in East Surabaya, Indonesia. The method used consists of determining the ratio between supply and demand in order to obtain the carrying capacity of the local environment. The results show that the carrying capacity in East Surabaya in the year 2030 is of conditional sustain and amounts to 1.0. Generally, the deficit status (overshoot) occurs between May and November and conditional sustain in April and December, with the condition of surplus (sustain) occurring from January to March. However, further action is needed to conserve water during the surplus months and thus meet the needs arising during the deficit months.
\end{abstract}

\author{
Keywords: \\ Carrying capacity; \\ East Surabaya; \\ Evapotranspiration; \\ Industry; \\ Water resource.
}

\section{Introduction}

Surabaya is the second biggest city in Indonesia after Jakarta, and is also known as one of the industrial cities with a population of 2.89 million [1]. As a metropolitan city that has continued to grow and develop over the years, Surabaya has played an important role as a social and economic hub, not only for the surrounding area, but also for Indonesia as a whole [2]. Much like in many other cities in developed countries, in Surabaya the provision of services is an important economic activity [3]. In addition, the industrial service sector is extremely well developed and continues to expand.

In terms of industrial activity, Surabaya is a major city. After Indonesia gained its independence, the city of Surabaya started to experience rapid growth in various types of industries. As a result, the Surabaya City Government has even taken the initiative to establish a special industrial estate location in the East Surabaya area. Here, many companies work with textiles, aluminium, and other materials. However, there is a need for more efficient government policies in terms of land use arrangements for industrial areas so as to encourage more effective utilization of the available space. This way, the allocated land can truly contribute (and bring value) to regional development, and the preparation of industrial estates, in general, is expected to facilitate development and industrial control [4].

Heydari et al. [5] state that water is the force powering life, so it is an element crucial to human survival. Nevertheless, the increased number of industries in the area has brought about changes in the land, which, in turn, has made it increasingly more difficult to find clean water in the city of East Surabaya. This is also related to the continuous increase in the population of Surabaya City. Urbanization is a substantial transformation of society which is currently taking place throughout the world [6], including in Surabaya. In 2018, the population growth amounted to 0.38 percent in the Surabaya City area with the growing rate of 0.47 percent per year from 2013 until 2018. In addition, the estimated density of Surabaya City reached 8844 inhabitants per km² in 2018 [1]. This contributed to the reduction of the water quantity available in the city. The industry is one of the largest consumers of natural resources [7], including water. According to Pirouzand and Maiolo [8], the world consumption of water in the industrial sector exceeds the consumption in the municipal sector. 
Surabaya gets flooded often (excess water), yet Perum Jasa Tirta Surabaya predicts that a water deficit will occur in 2025 [9]. Unavoidably, floods will become part of our lives. It might therefore be necessary to learn and understand the notion of water flood management in order to reduce damages and losses [10]. If the environmental carrying capacity of the water resources is carried out without environmental management, this will have an impact on water quantity fluctuations in Surabaya. According to Prastowo [11], the environmental carrying capacity of water resources can be determined by calculating the capacity of water availability, as per the dynamics of the hydrological cycle in the area. As a preservation effort, research is carried out on water balance-based environmental carrying capacity by means of data collection, data processing and calculations aimed at evaluating the condition of the water balance for several years. The results are to be used as reference for the community or city agencies [12].

An analysis of the environment carrying capacity based on the water resources of each sector of East Surabaya needs to be done. This is primarily to obtain data from the water balance analysis and use them as reference for the future development and water governance of East Surabaya. Such data is important because, according to Talent [13], the expanding need for resources which are otherwise scarce - such as drinkable water - emphasizes the necessity of efficient use and urban 'sustainability'. Improper use of natural sources, e.g. water, has a negative impact on living standards, notably in Surabaya [14]. Water resources and the advancement of water-related services are very much tied to public health and social security matters. For the purposes of this study, we consider these to be a public good [15].

It should be noted that water stress is projected to rise in various regions owing to climate change and a population boom, as well as increasing water demands for industries and cities [16]. Drawing on the results of this study, we can attempt to modify and/or implement strategies that help manage water and tackle such problems in other areas as well.

\section{Research method}

\subsection{Research location and trend change}

The determination of the environment's carrying capacity covers the total area of East Surabaya, with a density of 8,809 people per $\mathrm{km}^{2}$ in 2017 . The area is divided into 7 sub-districts, Table 1.

Trends are frequently analyzed with the help of a time series [17]. In this study, the trend change analysis is based on an estimation of population growth and projected onto several years. The analysis of the trend change was done using the TableCurve 2D software (data fitting method), where the $x$-axis represents the $n$-year and the $y$-axis explains the factors that impact the trend analysis [18], e.g. population, number of employees, and the area of each type of land used. The software will generate the best equation for the trend change, as well as the equation used to calculate the projections to be used until the year 2030 .

Table 1: East Surabaya sub-district.

\begin{tabular}{|c|c|c|}
\hline No. & Subdistrict & Area $\left[\mathbf{k m}^{2}\right]$ \\
\hline 1 & Tambaksari & 8.99 \\
\hline 2 & Gubeng & 7.99 \\
\hline 3 & Rungkut & 21.08 \\
\hline 4 & TenggilisMejoyo & 5.52 \\
\hline 5 & GunungAnyar & 9.71 \\
\hline 6 & Sukolilo & 23.68 \\
\hline 7 & Mulyorejo & 14.21 \\
\hline \multicolumn{2}{|c|}{} \\
\hline
\end{tabular}

\subsection{Calculation of water availability}

For the purpose of this study, the availability of water is found by calculating the amount of reliable rainfall that occurs in East Surabaya. To this end, we use the Weibull method, which was chosen due to its consistency and the assumption that the value obtained for reliable rainfall is closest to the truth [19]. 
The rate of monthly reliable rainfall used in this study is $80 \%$; in order to analyze it, we use data that has been collected during the past 10 years [20], i.e. the rainfall data was taken from the observer station Perak II and Juanda during the 2008 - 2017 period. From the 10 years of data, it is known that the highest average monthly rainfall occurs in June, with an average of $667.428 \mathrm{~mm}$, and the lowest average monthly rainfall is in August, with an average monthly rainfall of $81.29 \mathrm{~mm}$.

As such, the reliable rainfall is obtained through equation 1 :

$P=\frac{m}{n+1}$,

$P$ is rainfall opportunities; meanwhile, $m$ and $n$ are data order according to magnitude and number of data, respectively.

\subsection{Calculation of water demands}

Water demand is the total of domestic and non-domestic water demands, and evapotranspiration. Domestic water demands $\left(Q_{\text {domestic }}\right)\left[\mathrm{m}^{3} / \mathrm{month}\right]$ can be calculated by means of equation 2 . The non-domestic water demands $\left(Q_{\text {nondomestic }}\right)\left[\mathrm{m}^{3} / \mathrm{month}\right]$ considered for this calculation only come from the industrial sector as the main non-domestic water user in the region. Non-domestic water demand for the industry is calculated according to equation 3 .

$Q_{\text {domestic }}=$ water $_{\text {consumption }} \times$ population $\times$ day,

$Q_{\text {nondomestic }}=$ water $_{\text {consumption }} \times$ employee $\times$ day.

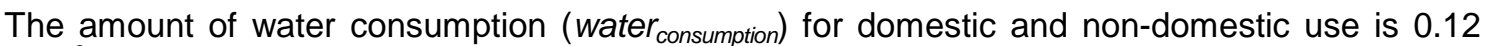
and 0.5 [ $\mathrm{m}^{3} /$ person/day], respectively [21]. Population is the total population in area [person]. Employee is the total number of employees in the area [person]. Day is the number of days in a month [day].

For the year 2030, the population and the number of employees were calculated using the equation found using TableCurve 2D, based on data from 2008 - 2017. From said data, it is known that population growth amounts to $1.89 \%$ per year. It is also projected that the population of East Surabaya will reach 1000405 people in 2030. Meanwhile, the employee growth equals $2.27 \%$ per year, and is projected to reach a total of 63537 employees in 2030.

Evapotranspiration $\left(E T_{c}\right)[\mathrm{mm} /$ day] in an area is a form of water loss. The evapotranspiration per land use type can be calculated using equations 4 - 8 [22 - 23]. In Surabaya, land is generally used for settlement, paddy fields, dry land, ponds, services and trade, industry, vacant land, etc. In this study, we focus on dry land and mixed gardens, as well as paddy fields with the crop coefficient value $\left(K_{c}\right)$; this value is shown in Table 2 [24].

$E T_{c}=k_{c} E T_{o}$,

$E T_{o}=0.000938 R_{S}\left(T_{\max }-T_{\min }\right)^{1 / 2}\left(T_{\text {ave }}+17.8\right)$,

$R_{s}=37.6 d_{r}\left(\omega_{s} \sin \varphi \sin \delta+\cos \varphi \cos \delta \cos \omega_{s}\right)$,

$d_{r}=1+0.033 \cos (0.0172 J)$,

$\omega_{s}=\arccos (-\tan \varphi \tan \delta)$,

$E T_{o}$ [mm/day] is potential evapotranspiration, $R_{s}$ is extra-terrestrial radiation [MJ $\left.\mathrm{m}^{-2} \mathrm{~h}^{-1}\right], T_{\max }, T_{\min }$, and $T_{\text {ave }}$ are maximum, minimum, and average temperature $\left[{ }^{\circ} \mathrm{C}\right]$, respectively, $d_{r}$ is relative distance from earth, $\omega_{s}$ is sunset hour angle [rad], $\varphi$ is latitude [rad], $\delta$ is solar declination [rad].

Table 2: Crop coefficient value and percent area of each land-use type.

\begin{tabular}{|c|c|}
\hline Land use type & $\boldsymbol{K}_{c}$ \\
\hline Dry land and mixed gardens & $0.8-0.9(0.85)$ \\
\hline Paddy fields & $0.8-1.15(0.975)$ \\
\hline
\end{tabular}


Evapotranspiration $\left(E T_{c}\right)$ [mm/day] is changed to Evapotranspiration $\left(E T_{c}\right)\left[\mathrm{m}^{3} / \mathrm{month}\right.$ in each land-use type by multiplying it with the area and the number of days in a month. The average area change in dry land, mixed gardens and paddy fields is $0.34 \%$ per year. The total value of evapotranspiration resulted for those types of land-use is then used as East Surabaya evapotranspiration.

\subsection{Environment carrying capacity}

According to Wang et al. [25], the concept of carrying capacity was initially introduced with regard to the population growth under the threat of wars and food shortages. The concept is therefore rooted in demography and biology, but also applied in ecology and the field of water resources. The environment carrying capacity based on the water resources available in a specific area is obtained by calculating the ratio between water availability (supply) and water demand (demand). Table 3 shows the criteria for determining the environment carrying capacity with a comparison of supply and demand ratios [11].

$W R C C=\frac{\text { supply }}{\text { demand }}$.

Table 3: DDL status determination criteria.

\begin{tabular}{|l|l|l|c|}
\hline \multicolumn{3}{|c|}{ Ratio } & Status \\
\hline & supply / demand & $>2$ & sustain \\
\hline $1 \leq$ & supply / demand & $\leq 2$ & conditional sustain \\
\hline & supply / demand & $<1$ & overshoot \\
\hline
\end{tabular}

The supplied value is the input value for water balance. That is obtained/calculated based on parameters related to water availability (reliable rainfall), while demand is related to the output value of the water balance, i.e. the parameters of water demand (total of domestic, non-domestic and evapotranspiration).

\section{Results and discussion}

\subsection{Water availability}

Rainfall is one of the important factors to be taken into account when calculating the availability of water as it plays a significant role in hydrological and environmental design [26], especially in East Surabaya. For the purpose of this research, rainfall data was taken from the meteorology stations of Perak II and Juanda. The rainfall used for the component of water availability is the reliable rainfall obtained with the Weibull method with an $80 \%$ chance.

From these data in Fig. 1, it is concluded that the highest reliable rainfall occurred in March, and the lowest occurred between August and October. Based on Avia [27], this rainfall is a monsoonal type with a maximum occurrence value situated at around 14.00 to 20.00 LST (GMT+7). This pattern shows a direct response to warming which occurs at the exterior boundary of the troposphere during the day.

The availability of water in East Surabaya is calculated by multiplying the reliable rainfall value of $80 \%$ with the area of it. The amount of water available in each region is shown in Fig. 2, with a total of $109,256,361 \mathrm{~m}^{3}$ per year. According to Zhang and Zhou [28], precipitation-related extremes are most influenced by climate change and the consequential rise in temperature. Future climate projections do not make significant effects on the average annual precipitation volume [29], but we should be aware of projections that indicate an increase in intense precipitation. Therefore, water harvest technology is needed in order to save excess water and save it for future shortages. 


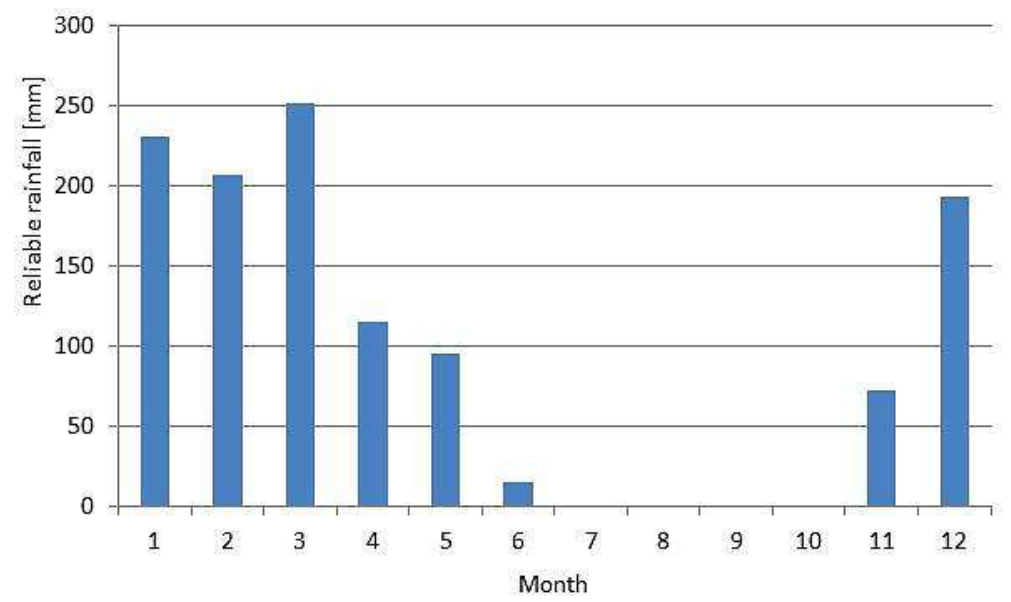

Fig. 1: Reliable rainfall.

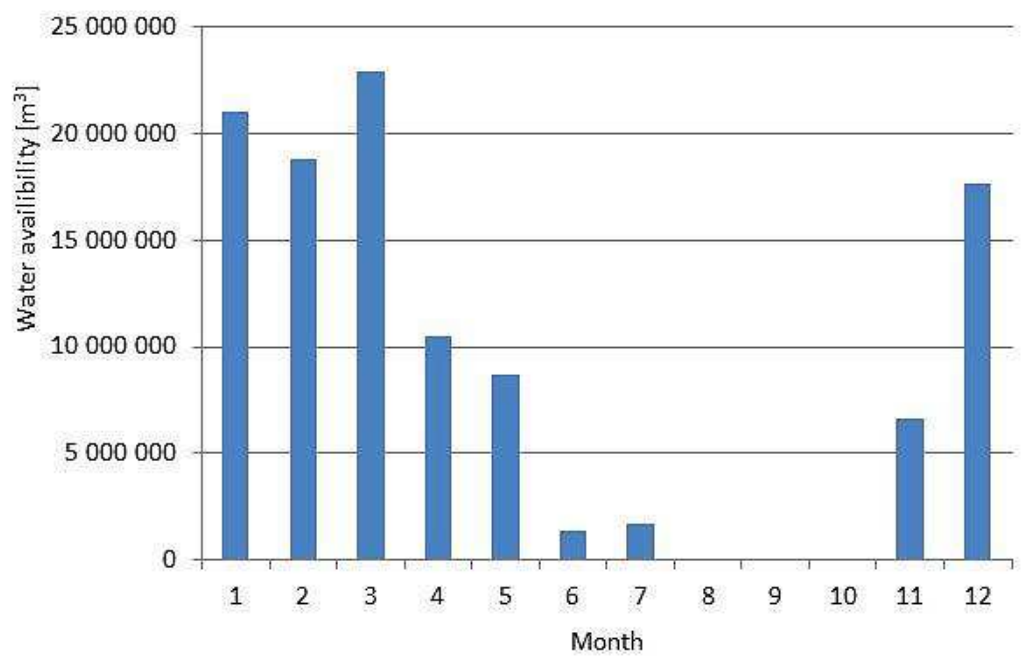

Fig. 2: East Surabaya water availability.

\subsection{Water demands}

In this study, water demand is divided into 2 (two) categories, i.e. domestic and non-domestic water requirements according to SNI 19-6728.1-2002 [21]. Domestic water needs include the water needs of the population, while non-domestic water needs are industrial water needs, as well as water loss in the form of evapotranspiration $\left(E T_{c}\right)$. Fig. 3 shows the water demands in detail. Based on the analysis, in 2030, water demand in East Surabaya will be $118513606 \mathrm{~m}^{3}$, showing an annual increase of $1 \%$. The peak as far as water demands are concerned will be reached in May, at 10080 $665 \mathrm{~m}^{3}$.

Much like Li et al. [30], we cannot construct substantial appraisals of the impact of climate change on water demand, especially when it comes to domestic and non-domestic water use. Although the future state of the climate will possibly have a negative impact on water use, there is not enough data on the variability of it related to climate change in East Surabaya. Therefore, we assume that both the demand and the population will increase, and the predicted monthly demand in 2030 will only appear different because of the varying number of days in each month.

Other sources of water demand, e.g. evapotranspiration, cannot be neglected in East Surabaya; evapotranspiration plays a key role in the different rates of water demand each month. Even though urban evapotranspiration, including in East Surabaya, is appreciably below rural areas by the hydrological properties of building materials and vegetation-covered soils counterpoint, yet the vegetated surfaces cover in certain areas remain substantial [31]. In the future, warmer temperatures may increase the rate of evaporation, even if local conditions do have an impact as well. A rise in temperature that is more accelerated than the intensity of precipitation could lead to a lower difference between rainfall and potential evaporation. In other words, the soil will become drier. This needs to be considered and anticipated, because it can affect water availability and supply [29]. 
The value of evapotranspiration is influenced by how the land is used and varies according to the population growth in East Surabaya. In time, the need for water in East Surabaya will change due to the rise in social and economic activities, along with an increase in the consumption of natural resources and the strain exerted by the growing population on the available land. Urbanization and migration trigger changes in East-Surabaya's land-use [32].

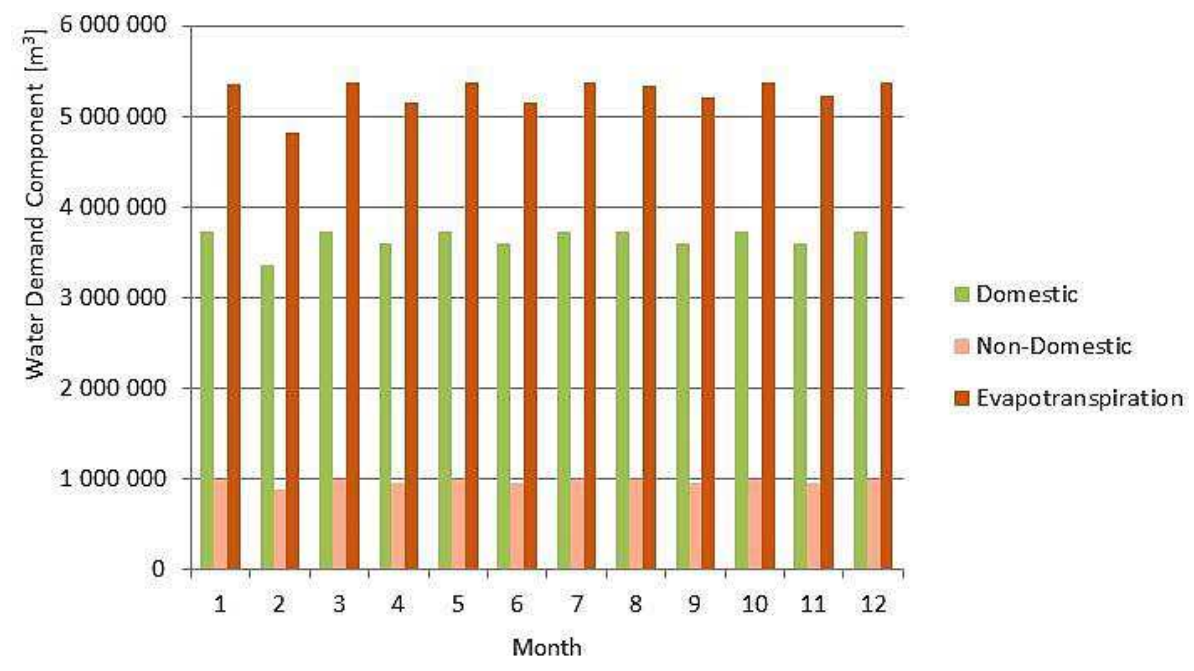

Fig. 3: East Surabaya water demands.

\subsection{Water balances}

Water balance is the science of hydrometeorology and is calculated as the relationship between inflow and outflow during a certain period of time within an area. The amount of excess (surplus) or deficit water can be determined by analyzing the water balance. In order to improve urban water management, it is important to understand the interrelations present in the water cycle. [33].

The condition of the water balance in East Surabaya can be seen in Fig. 4. The surplus conditions appear to occur in December-April. The deficit conditions that occur in East Surabaya are due to the fact that water demand is higher than the amount of available water. The data shows that, in 2030, the deficit begins from May to November with total annual deficit reach $-4711832 \mathrm{~m}^{3}$. A water deficit is a more suitable metric compare to water scarcity when it comes to showing that there is not enough water available to meet demand during a particular month. In such a case, water demand remains unmet or can only be supplied by costlier and/or less sustainable means [34].

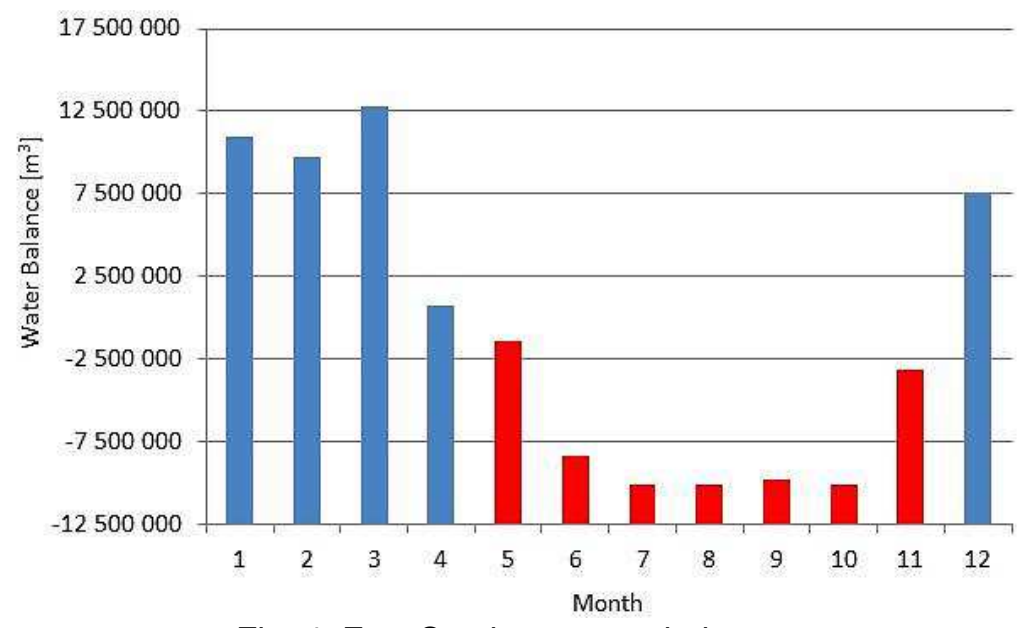

Fig. 4: East Surabaya water balance.

\subsection{Environment carrying capacity}

The carrying capacity of the water resources available is becoming a major issue in urban planning. The concept can be defined as the level of human activity that can be sustained by the water resources, 
ensuring an adequate living standard without major degradation of the environment. The criteria for the carrying capacity of the environment can be expressed by the supply/demand ratio or by the value of the surplus-deficit.

The environmental carrying capacity in East Surabaya can be determined by comparing the level of water demand to the available water. The environmental carrying capacity status calculated in this study on East Surabaya can be seen in Fig. 5. The environmental carrying capacity of East Surabaya in 2030 can be found in the conditional sustain category, with an average ratio of 1.0 (conditions between 1 and 2). However, it should be noted that the deficit condition (overshoot) occurs in 7 months, from May to November, due to the fact that water demand exceeds the amount of water available.

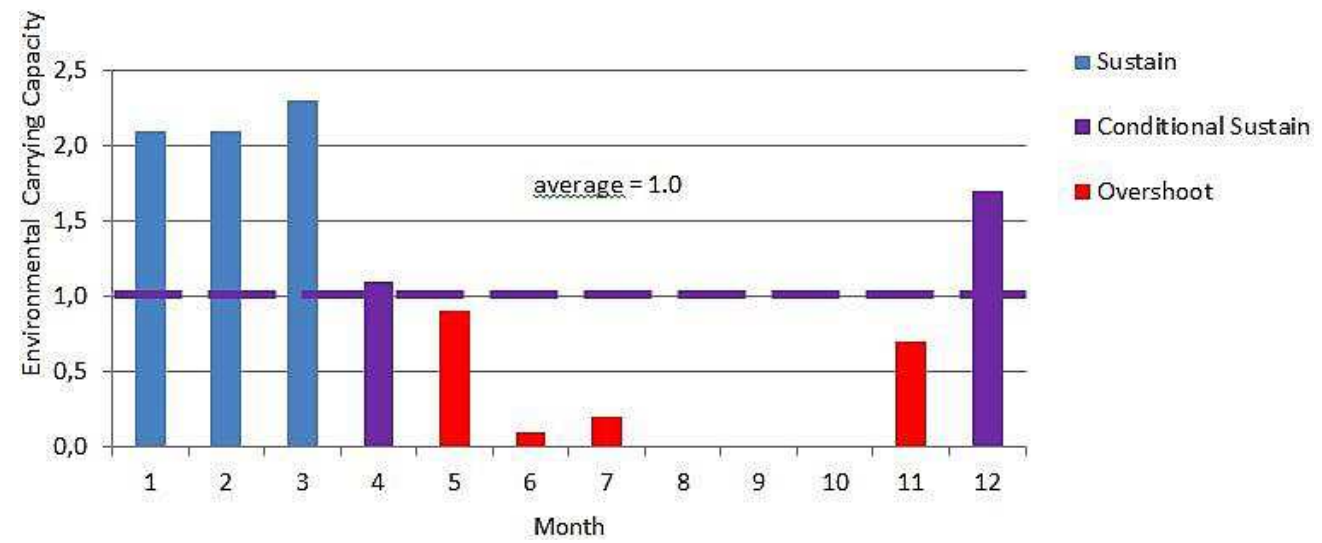

Fig. 5: East Surabaya Environmental Carrying Capacity Ratio in 2030.

Raising awareness about water demand behaviors and upgrading water-saving devices are essential steps to minimizing residential water demand. Another sustainable approach might also need to be applied in order to deal with deficit months (overshoot) in East Surabaya. The strategy could consist of decentralizing water harvesting, storage and reuse. The purpose of harvesting rain and stormwater is to collect, treat and reserve water when it is still available and thus be able to counteract periods of shortage [33].

In order to solve overshoot conditions, we need a technical solution which is not limited to shortterm storage. In fact, a seasonal reservoir with a long-term storage capacity may prove to be significantly more efficient. Hence, we propose a new boezem in East Surabaya. Boezem is an estuary from the Surabaya drainage channel which also functions as a means of controlling floods [36]. Boezem itself is much like a reservoir and works similarly to a natural source of water, but differs from the latter in the sense that its contents come from rainfall.

If the rainfall is insufficient, the next source available for use is river water, followed - to a much lower extent - by groundwater. It should be noted that the climate crisis will allegedly worsen the effects of groundwater exploitation in cities, e.g. deplete water tables, pollute the surface water, and enhance salinization. Often, groundwater sources are also insufficient or of poor quality due to brackish conditions and salination, aside from domestic and industrial pollution [37]. In the study area, groundwater usage is minimized due to the coastal location of East Surabaya, which is often susceptible to groundwater contamination by means of salty water.

\section{Conclusion}

The environmental carrying capacity of East Surabaya in 2030 is mostly in deficit (overshoot) conditions from May to November. The sustain (surplus) conditions occur in January, February, and March. An excess water management strategy needs to be put in place during the months of surplus in order to ensure the sustainability of water resources.

\section{References}

[1] SURABAYA CENTRAL BUREAU OF STATISTICS. Statistik Kota Surabaya, Surabaya City Statistics, in Indonesian. BPS, Surabaya, 2019.

[2] PAMUNGKAS, A. - IRANATA, D. - YUWONO, J. - JAELANNI, L. M.: An Insight on Surabaya Development: Pre-Colonials, Colonial, Post-Colonial and Current Era. IOP Conference Series: Earth and Environmental Science, Surabaya, Indonesia, 2018, p. 012002. 
[3] JUODKIENĖ, V.: GIS In Tourism Development Using Spatial Modelling. Civil and Environmental Engineering, Vol. 10, Iss. 2, 2014, pp. 98-104.

[4] PUTRI, D. A.: Kawasan Industri Rungkut Tahun 1965-1980. Rungkut Industrial Estate in 19651980, in Indonesian. Avatara, E-Journal Pendidikan Sejarah, Vol. 6, Iss. 2, 2018, pp. 68-74.

[5] HEYDARI, M. M. - ABBASI, A. - ROHANI, S. M. - HOSSEINI, S. M. A.: Correlation Study and Regression Analysis of Drinking Water Quality in Kashan City, Iran. Walailak J.Sci. \& Tech. Vol. 10, Iss. 3, 2013 pp. 315-324.

[6] GOPINATH, R. - BANERJEE, A. - SACHIN, S. - TIWARI, P. - WILSON, S.: Real-Time Thermal Mapping for Heat \& Cool Archipelagos of Bengaluru, India. Civil and Environmental Engineering, Vol. 13, Iss. 2, 2017, pp. 106-111.

[7] PETKOVA-SLIPETS, R. - ZLATEVA, P.: Thermal Insulating Properties of Strawfilled Environmentally Friendly Building Materials. Civil and Environmental Engineering, Vol. 13, Iss. 1, 2017, pp. 52-57.

[8] PIROUZ, B. - MAIOLO, M.: The Role of Power Consume and Type of Air Conditioner in Direct and Indirect Water Consumption. J. Sustain. Dev. Energy Water Environ. Syst. Vol. 6, Iss. 4, 2018, pp. $665-73$.

[9] FITRIATIEN, S. R. - IRAWAN, M. I. - KARNANINGROEM, N.: Pola Sebaran Polutan di Kali Surabaya Menggunakan Jaringan Kohonen. Pattern of Pollutant Distribution in Surabaya River Using Kohonen Network (in Indonesian). Prosiding Seminar Teknologi Lingkungan, Surabaya, Indonesia. 2014, pp. 148-55.

[10] RUAIRUEN, W. - JAROENSUTASINEE, K. - JAROENSUTANEE, M.: Flash Flooding Area Prediction by GOES-9 Satellite Data. Walailak J.Sci. \& Tech. Vol. 2, Iss. 2, 2005, pp. 135-48.

[11] PRASTOWO. Daya Dukung Lingkungan Aspek Sumberdaya Air. Environmental Carrying Capacity of Water Resources Aspects (in Indonesian). IPB University, Bogor, 2010.

[12] ARTHA, E. U. - RAHADI, B. - SUHARTO, B.: Evaluasi Daya Dukung Lingkungan Berbasis Neraca Air di Kota Batu. Evaluation of Carrying Capacity Based on Water Balance in Batu City (in Indonesian). Jurnal Sumberdaya Alam dan Lingkungan, Vol. 1, Iss. 3, 2014, pp. 68-74.

[13] TALENT, M.: Smarter Cities: Cleaning Electricity, Gas and Water Metered Consumption Data for Social and Urban Research. J. Sustain. Dev. Energy Water Environ. Syst. Vol. 7, Iss. 3, 2019, pp. 466-81.

[14] MOHAMMADIAN, Z. - SHAHBAZI, M.: Study of the Effect of Sustainable Architecture on the Design of Residential Buildings (Case Study: Qazvin Pardis Complex). Civil and Environmental Engineering, Vol. 14, Iss. 2, 2018, pp. 91-98.

[15] SEMERTZIDIS, Z. - SPATARU, C. - BLEISCHWITZ, R.: The Nexus: Estimation of Water Consumption For Hydropower In Brazil. J. Sustain. Dev. Energy Water Environ. Syst., Vol. 7, Iss. 1, 2019, pp. 122-138.

[16] CARVALHO, P. - SPATARU, C. - BLEISCHWITZ, R.: Integration of Water and Energy Planning to Promote Sustainability. J. Sustain. Dev. Energy Water Environ. Syst., Vol. 7, Iss. 2, 2019, pp. 229-252.

[17] SHARMA, S. - SWAYNE, D. A. - OBIMBO, C.: Trend Analysis and Change Point Techniques: A Survey. Energ. Ecol. Environ., Vol. 1, Iss. 3, 2016, pp. 123-130.

[18] HASANAH, N. A. I. - SETIAWAN, B. I. - ARIF, C. - WIDODO, S.: SRI Paddy Growth Simple Prediction Model. IJCIET, Vol. 8, Iss. 6, 2017, pp. 423-429.

[19] BHAKAR, S. R. - IQBAL, M. - DEVANDA, M. - CHHAJED, N. - BANSAL, A. K.: Probablity Analysis of Rainfall at Kota. Indian J. Agric. Res., Vol. 42, Iss. 3, 2008, pp. 201-206.

[20] JUWONO, P. T. - LIMANTARA, L. M. - ROSIADI, F.: Optimization of irrigation Cropping Pattern By Using Linear Programming: Case Study on Irrigation Area of Parsanga, Madura Island, Indonesia. Journal of Water and Land Development, Vol. 39, Iss. X-XII, 2018, pp. 51-60.

[21] SNI 19-6728.1-2002: Penyusunan Neraca Sumber Daya - Bagian 1: Sumber Daya Air Spasial (Compilation of Resource Balance - Part 1: Spatial Water Resources, in Indonesian). Badan Standardisasi Nasional, Jakarta, 2002.

[22] ALLEN, R. G. - PEREIRA, L. S. - RAES, D. - SMITH, M.: Crop Evapotranspiration (Guidelines for Computing Crop Water Requirements). FAO, Rome, 2006.

[23] HASANAH, N. A. I. - SETIAWAN, B. I. - ARIF, C. - WIDODO, S.: Muka Air Optimum Pada System of Rice Intensification (SRI) [Optimum Water Level for System of Rice Intensification (SRI), in Indonesian]. Irigasi, Vol. 12, Iss. 1, 2017, pp. 55-64.

[24] DOORENBOS, J. - PRUITT, W. O.: Guidelines for Predicting Crop Water Requirements. FAO, Rome, 1977.

[25] WANG, L. - WANG, Z. - LIU, X.: Water Resources Carrying Capacity Analysis of YarLung Tsangpo River Basin I. Water, Vol. 10, Iss. 1131, 2018, pp. 1-15. 
[26] PRIAMBODO, S. - SUHARDJONO - MONTARCIH, L. - SUHARTANTO, E.: Hourly Rainfall Distribution Patterns in Java Island. MATEC Web of Conferences 276; ICAnCEE 2018, Bali, Indonesia. 2019, p.04012.

[27] AVIA, L. Q.: Diurnal Patterns of Cloud Top Temperature and Rainfall for Three Types of Rainfall Inindonesia. SNSAA Proceeding, Bandung, Indonesia. 2014, pp. 287-297.

[28] ZHANG, W. - ZHOU, T.: Increasing Impacts from Extreme Precipitation on Population over China with Global Warming. Science Bulletin, Vol. 65, 2020, pp. 243-252.

[29] MARGANINGRUM, D. - SANTOSO, H.: Evapotranspiration of Indonesian Tropical Area. Jurnal Presipitasi, Vol 16, No 3, 2019, pp. 106-116.

[30] LI, M. - FINLAYSON, B. - WEBBER, M. - BARNETT, J. - WEBBER, S. - ROGERS, S. - CHEN, Z. - WEI, T. - CHEN, J. - WU, X. - WANG, M.: Estimating Urban Water Demand under Conditions of Rapid Growth: The Case of Shanghai. Reg Environ Change, Published online Januari, 2017, pp. 1-9.

[31] GRIMMOND, C. S. B.: Evapotranspiration Rates in Urban Areas. In: Proceedings of IUGG 99 Symposium HS5, Birmingham. 1999, pp. 235-243.

[32] SURYA, B. - AHMAD, D. N. A. - SAKTI, H. H. - SAHBAN, H.: Land Use Change, Spatial Interaction, and Sustainable Development in the Metropolitan Urban Areas, South Sulawesi Province, Indonesia. Land, Vol. 9, Iss. 95, 2020, pp. 1-43.

[33] ZEISL, P. - MAIR, M. - KASTLUNGER, U. - BACH, P. M. - RAUCH, W. - SITZENFREI, R. KLEIDORFER, M.: Conceptual Urban Water Balance Model for Water Policy Testing: An Approach for Large Scale Investigation. Sustainability, Vol. 10, Iss. 716, 2018, pp. 1-24.

[34] BIJL, D. L. - BIEMANS, H. - BOGAART, P. W. - DEKKER, S. C. - DOELMAN, J. C. STEHFEST, E. - VAN VUUREN, D. P.: A Global Analysis of Future Water Deficit Based On Different Allocation Mechanisms. Water Resources Research, Published online 2018, pp. 58035824.

[35] AIT-AOUDIA, M. N. - BEREZOWSKA-AZZAG, E.: Water Resources Carrying Capacity Assessment: The Case of Algeria's Capital City. Habitat International, 58, 2016, pp. 51-58.

[36] FITRIANINGTYAS, R. - SLAMET, A.: Studi Pemetaan Persebaran Sedimen Boezem Morokrembangan [Study of Boezem Morokrembangan Sediment Distribution Mapping, in Indonesian]. Jurnal Teknik ITS, Vol. 7, Iss. 1, 2018, pp. 2337-3520.

[37] LOENS, S.: Thirsty Cities: Learning From Dutch Water Supply Heritage. In: C Hein (eds) Adaptive Strategies for Water Heritage. Springer, Cham, 2020. 